\title{
Role of the insulin-like growth factor system in gonad sexual maturation in Pacific oyster Crassostrea gigas
}

\author{
Ji-Sung Moon ${ }^{1}$ and Youn Hee Choi ${ }^{1,2^{*}}$ (D)
}

\begin{abstract}
Background: The IGF system plays important roles in controlling growth, development, reproduction, and aging of organisms.

Methods: To estimate maturation of the Pacific oyster Crassostrea gigas, we investigated the expression of insulinlike growth factor (IGF) system components and sex-specific genes. To determine the role of the IGF system in the growth and spawning period of female and male oysters, we examined mRNA expression levels of the C. gigas insulin receptor-related receptor (CIR), IGF binding protein complex acid labile subunit (IGFBP_ALS), and molluscan insulin-related peptide (MIP), as well as those of vitellogenin (Vg) and receptor-type guanylate cyclase (Gyc76C) in gonads of $C$. gigas collected between April and October, when sex can be determined visually in this species.

Results: We found that MIP, IGFBP_ALS, and CIR mRNA expression levels were dependent on sex and month and were greater in males than in females. CIR and Vg mRNA expression levels were very similar among females, whereas IGF system components and Gyc76C were very similarly expressed among males. The highest expression values were observed in May, when oysters are mature; CIR and Vg mRNA expression levels were highest in females, and those of MIP, IGFBP_ALS, $\mathrm{CIR}$, and Gyc76C were highest in males. Interestingly, we observed a 1:1 proportion of females to males during this period.

Conclusion: Our results suggest that IGF system components, as well as Vg and Gyc76C, are associated with sexual maturation in C. gigas.
\end{abstract}

Keywords: Pacific oyster, Gonad, IGF system, Vitellogenin, Gyc76C

\section{Background}

The IGF system, which plays important roles in controlling vertebrate growth and development, comprises three components: ligands (IGF-I and -II), receptors (types I and II), and IGF-binding proteins (IGFBPs) (Duan 1997). The existence of traditional IGFs, IGF receptors, and IGFBPs has not been positively demonstrated in invertebrates (Huang et al. 2015). However, several insulin-like peptides (ILPs) have been discovered; these function in a variety of biological processes including growth, metabolism, molting, and reproduction (Nagasawa et al. 1986; Krieger et al. 2004; Wu and Brown 2006; Grönke et al. 2010; Marquez et al. 2011; Ventura et al. 2011; Chung

\footnotetext{
* Correspondence: unichoi@pknu.ac.kr

${ }^{1}$ Department of Fisheries Biology, Pukyong National University, Busan 48513, Republic of Korea

${ }^{2}$ Department of Marine Bio-Materials and Aquaculture, Pukyong National University, Busan 48513, Republic of Korea
}

2014; Huang et al. 2015). Insulin receptor homologs, which exhibit structural and functional similarities to IGF receptors, have also been widely reported (Brogiolo et al. 2001; Nässel et al. 2015). In mollusks, growth and associated metabolic processes are regulated under the control of neural ganglia (Gricourt et al. 2003). Molluscan insulin-related peptides (MIPs) have been identified in many gastropods and bivalves as functional substances in neural ganglion neurosecretory cells (Roovers et al. 1995; Gricourt et al. 2003). In particular, MIPs have a beneficial effect on soft body and shell growth (Geraerts 1976, 1992; Gricourt et al. 2003). Geraerts et al. (1992) reported the various functions of MIPs according to stimulus-dependent differential patterns of MIP gene expression in the central nervous system. Recently, studies have been performed to examine the biological effects of various growth factors including

(c) The Author(s). 2020 Open Access This article is distributed under the terms of the Creative Commons Attribution 4.0 International License (http://creativecommons.org/licenses/by/4.0/), which permits unrestricted use, distribution, and reproduction in any medium, provided you give appropriate credit to the original author(s) and the source, provide a link to the Creative Commons license, and indicate if changes were made. The Creative Commons Public Domain Dedication waiver (http://creativecommons.org/publicdomain/zero/1.0/) applies to the data made available in this article, unless otherwise stated. 
Crassostrea gigas insulin receptor-related receptor (CIR) and IGFs in the mussel Mytilus galloprovincialis (Canesi et al. 1997, 1999, 2001), the Pacific oyster C. gigas (Gricourt et al. 2003; Jouaux et al. 2012), and the Yesso scallop Patinopecten yessoensis (Feng et al. 2014). These factors affect growth, maturation, and reproduction in a manner dependent on seasonal environmental conditions. Jouaux et al. (2012) reported a balance between growth and management of environmental stresses during reproduction and emphasized the involvement of insulin signaling in gametogenesis and reproduction in $C$. gigas. Many studies have reported intraspecific variation in growth and reproduction in a variety of invertebrates; among these, $C$. gigas has been used as a bivalve assessment model (Macdonald \& Thompson 1988; Bayne 1999; Choi et al. 2018).

C. gigas is an important aquaculture product that is mainly produced off the southern coast of Korea. However, the aquaculture production of oysters in Korea declined from 321,276 tons in 2007 to 303,183 tons in 2018 (MOF 2020). There was a similar tendency in the worldwide aquaculture production (FAO 2020). Oyster value is dependent on condition; however, fishing environments are becoming increasingly polluted due to high-density rearing, contaminated runoff from the coast, and climate change. As a result of physical activity by the parent oyster in such farming environments, oyster larval health is reduced, resulting in mass destruction and repeated seedling shortages. Oysters produced in coastal areas that have become clearer and cleaner through nitrogen and phosphorus regulation fail to gain weight due to a lack of food suitable for shellfish. These phenomena have unfavorable effects on oyster growth and maturity.

In this study, to estimate maturation of $C$. gigas oysters, we investigated the expression of various IGF system components. To determine the role of the IGF system in the growth and spawning of male and female oysters, we determined CIR, IGFBP_ALS, and MIP mRNA expression levels and those of sex-specific genes such as vitellogenin in C. gigas gonads.

\section{Methods}

\section{Sample preparation}

We collected 30-40 C. gigas individuals every month from April to October in 2017 (when gonads can be discriminated visually) at an oyster farm in Tongyeong, Gyeongsangnam-do, Korea $\left(34^{\circ} 51^{\prime}\right.$ 32.34" N, $128^{\circ} 12^{\prime} 23.44^{\prime \prime}$ E). We measured shell length (SL), shell height (SH), shell width (SW), total wet weight (TW), and soft tissue weight (STW) using a Vernier caliper (Mitutoyo, Kawasaki,
Japan) and a digital balance (AJ Vibra, Shinko Denshi, Japan). Male and female gonad pieces were dissected, immediately frozen in liquid nitrogen, and stored at $-75{ }^{\circ} \mathrm{C}$ until use.

\section{Protein identification}

We investigated protein expression in gonads using $8 \%$ sodium dodecyl sulfate-polyacrylamide gel electrophoresis (SDS-PAGE). Specific proteins were confirmed using tandem mass spectrometry (MS/MS) and electrospray ionization quadrupole time-of-flight MS/MS (ESIQ-TOF MS/MS, ABI, USA) as previously described (Choi et al. 2015). Proteins were identified via the National Center for Biotechnology Information (NCBI; https://www.ncbi.nlm.nih.gov) and UniProt Knowledgebase (http://www.uniprot.org/uniprot) databases using the MASCOT program (Matrixscience, London, UK).

\section{cDNA synthesis and reverse-transcription polymerase chain reaction (RT-PCR)}

Male and female gonads were pulverized by adding $1 \mathrm{~mL}$ Trans-Zol UP (TransGen Biotech, Beijing, China), and total RNA was extracted using Trans-Zol UP according to the manufacturer's instructions. cDNA was synthesized from $2 \mu \mathrm{g}$ total RNA using the PrimeScript firststrand cDNA synthesis kit (TaKaRa Bio, Otsu, Japan) according to the manufacturer's instructions. RT-PCR was performed using Emerald Amp GT PCR Master Mix (TaKaRa Bio, Otsu, Japan). Each primer set was designed according to sequences of CIR (accession no. AJ 535669.1), IGFBP_ALS (XM_011417921.2), MIP (NM_ 001308866.1), Gyc76C (XM_011452292.2), Vg (AB084783.1), and EF1 $\alpha$ (AB122066.1) (Table 1). PCR amplification was performed using $C$. gigas template cDNA with the following parameters: 1 cycle at $95^{\circ} \mathrm{C}$ for $5 \mathrm{~min}, 25$ cycles at $95^{\circ} \mathrm{C}$ for $30 \mathrm{~s}, 50^{\circ} \mathrm{C}$ for $30 \mathrm{~s}$, and $72{ }^{\circ} \mathrm{C}$ for $30 \mathrm{~s}$, followed by 1 cycle at $72{ }^{\circ} \mathrm{C}$ for $5 \mathrm{~min}$. PCR products were analyzed by gel electrophoresis on $1 \%$ agarose gels. Densitometry was conducted using the GeneTools v. 4.03 software (Syngene, Cambridge, UK).

\section{Statistical analyses}

Data are presented as means \pm standard deviations. Significant differences among means were tested using oneway analysis of variance (ANOVA) in the SPSS v. 10.0 software environment (SPSS, Inc., Chicago, IL).

\section{Results}

\section{Growth parameters}

We collected 40 C. gigas individuals monthly from April to October 2017, except in June. The ratio of females to males differed each month, being about 1:1 in May and September and 2:1 in June and July (Fig. 1). One hermaphrodite was found in May and one in 
Table 1 Nucleotide sequences of primers used in reverse-transcription polymerase chain reaction (RT-PCR) analysis of adductor muscles of the Pacific oyster Crassostrea gigas

\begin{tabular}{|c|c|c|c|}
\hline Gene & Accession no. & Sequence $\left(5^{\prime}-3^{\prime}\right)$ & Amplicon (bp) \\
\hline CIR & AJ535669 & $\begin{array}{l}\text { (F)-TGAGGAGGGTGATGAGGATA } \\
\text { (R)-ATTGCACTGTAGGGATTGGA }\end{array}$ & 375 \\
\hline IGFBP-ALS & XP_011442465.1 & $\begin{array}{l}\text { (F)-CTTGCCCTGAAAACCCTACA } \\
\text { (R)-GGGCAAGTAGCAGAATTTGG }\end{array}$ & 500 \\
\hline MIP & XM_011417420.2 & $\begin{array}{l}\text { (F)-TAAATACAAGCGGTCGGGTG } \\
\text { (R)-AGATCCTTTCTTCTTGCGGC }\end{array}$ & 214 \\
\hline Gyc76C & XM_011452292.2 & $\begin{array}{l}\text { (F)-ATGAATGCAGTGAATCGCTTGA } \\
\text { (R)-TGATACTGTGCAGCTCTTGG }\end{array}$ & 274 \\
\hline Vg & AB084783.1 & $\begin{array}{l}\text { (F)-ATGCTGGAGATGAACCTTGAG } \\
\text { (R)-TGCTTCGTGGTGGATATCCT }\end{array}$ & 273 \\
\hline EFla & AB122066.1 & $\begin{array}{l}\text { (F)-CCACTGGCCATCTCATTTAC } \\
\text { (R)-TGTTGACACCAATGATGAGC }\end{array}$ & 393 \\
\hline
\end{tabular}

$b p$, base pairs; $F$, forward; $R$, reverse; $C I R, C$. gigas insulin receptor-related receptor; IGFBP-ALS, insulin-like growth factor binding protein complex acid labile subunit; MIP, molluscan insulin-related peptide; Gyc76C, receptor-type guanylate cyclase; $V g$, vitellogenin

June; the proportion of males was higher than that of females in August (Fig. 1).

The ratios of STW to TW ranged from 0.07 to 0.29 (mean, $0.15 \pm 0.04$ ) and 0.08 to 0.34 (mean, $0.16 \pm 0.04$ ) in females and males, respectively (Fig. 2a, c). The ratio of SH to SL ranged from 1.35 to 3.58 (mean, $2.07 \pm 0.37$ ) and from 1.02 to 3.36 (mean, $2.07 \pm 0.36$ ) in females and males, respectively (Fig. $2 \mathrm{~b}, \mathrm{~d}$ ). The ratio of SW to SL ranged from 0.07 to 0.29 (mean, $0.15 \pm 0.04$ ) and from
0.08 to 0.34 (mean, $0.16 \pm 0.04$ ) in females and males, respectively (Fig. 2b, d). Thus, growth rates of STW/TW, $\mathrm{SH} / \mathrm{SL}$, and SW/SL were positive in both females and males in this study (Fig. 2).

\section{Protein identification}

Protein expression differed between males and females in this study. Proteins were identified as vitellogenin-6 C-term fragments of $180 \mathrm{kDa}$ and $\mathrm{N}$ -

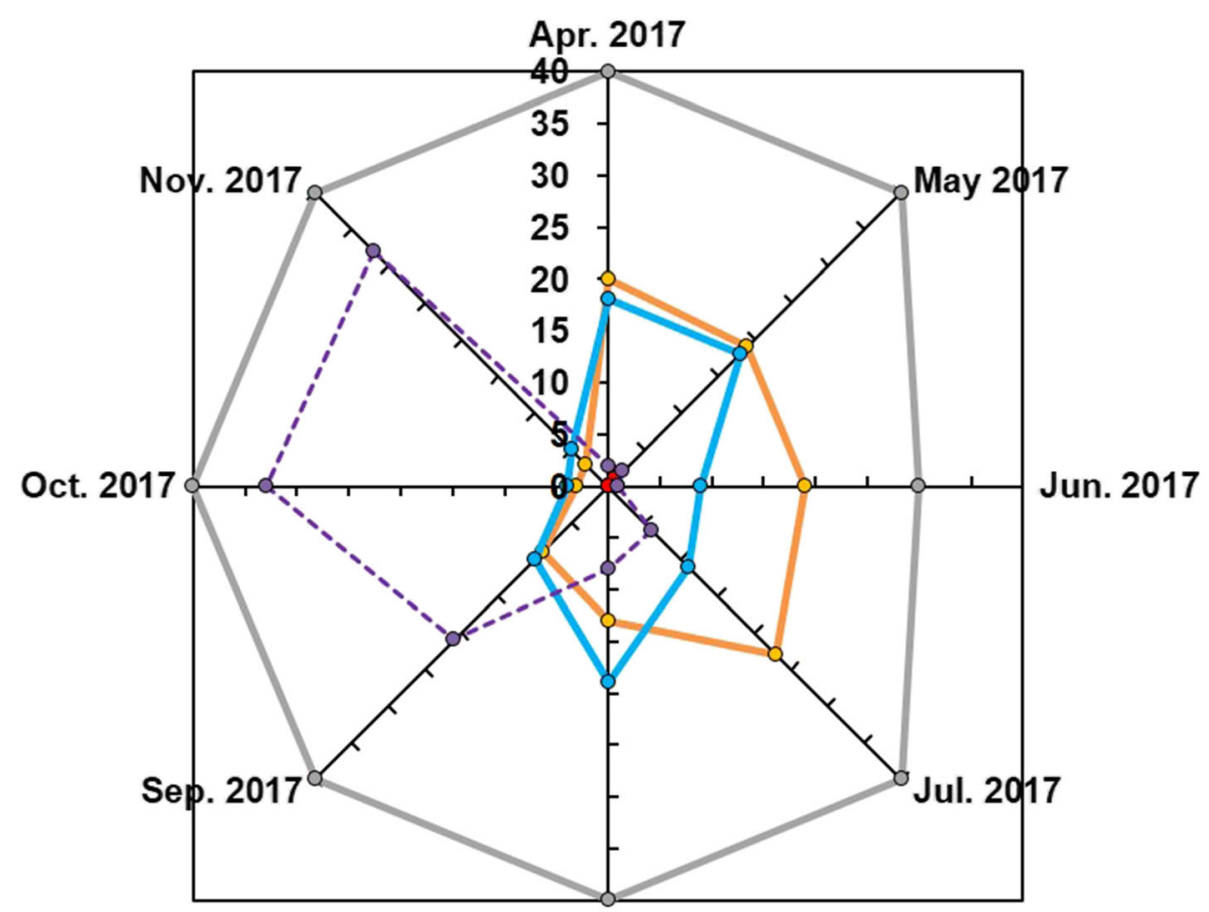

Aug. 2017

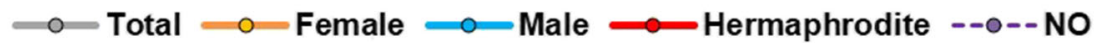

Fig. 1 The ratio of females to males in the Pacific oyster Crassostrea gigas from April to October. NO, not observed 


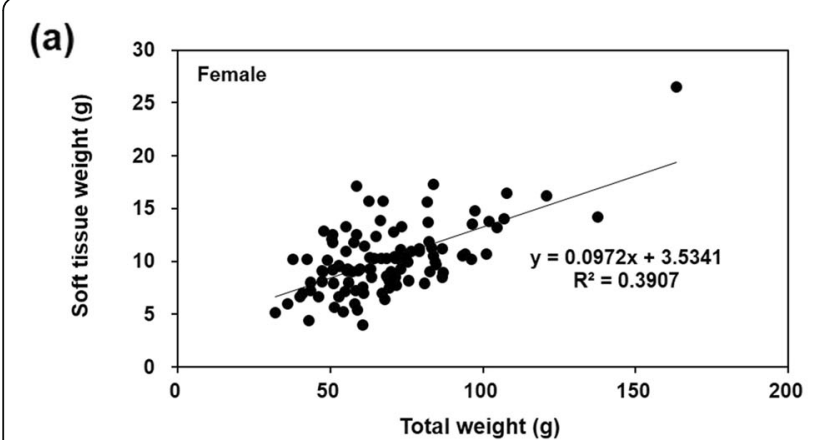

(c)

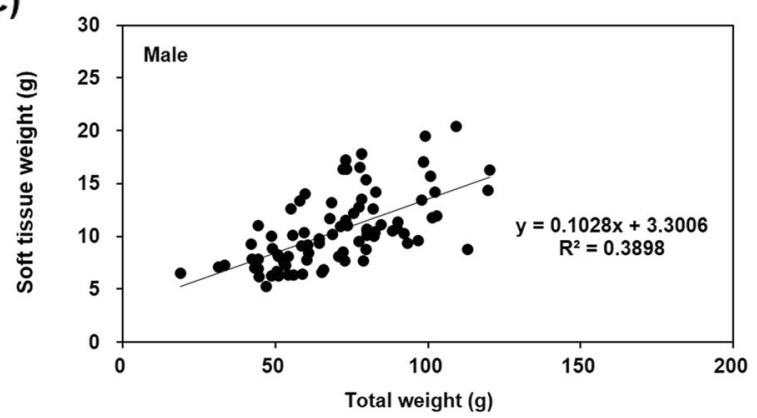

(b)

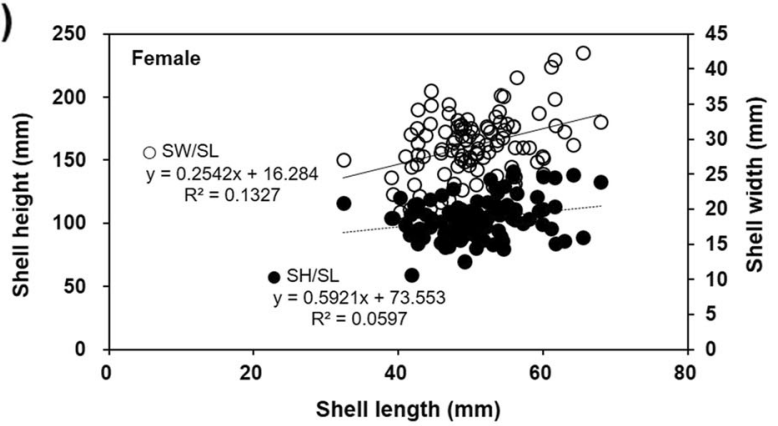

(d)

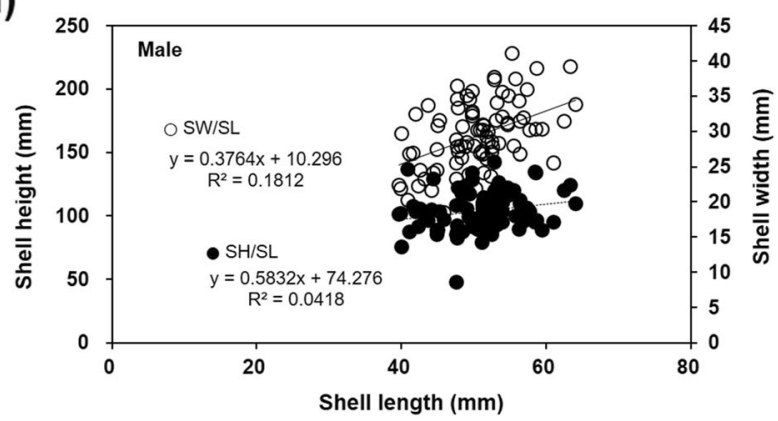

Fig. 2 C. gigas growth during the collection period (April-October 2017). a Growth of soft tissue and total weight in female oysters. b Growth of shell height and length in female oysters. c Growth of soft tissue and total weight in male oysters. $\mathbf{d}$ Growth of shell height and length in male oysters

term fragments of $110 \mathrm{kDa}$ (accession no. tr|K1QNA2|K1QNA2_CRAGI, https://www.uniprot. org/uniprot/K1QNA2) in females and guanlylate cyclase (Gyc76C) protein of $96 \mathrm{kDa}$ (accession no. tr|K1QS46|K1QS46_CRAGI, https://www.uniprot.org/ uniprot/K1QS46) mixed with $143 \mathrm{kDa}$ of uncharacterized protein in males (Fig. 3).

MIP, IGFBP_ALS, CIR, Vg, and Gyc76C expression analysis Among components of the IGF system (MIP, IGFBP_ ALS, and CIR), mRNA expression was greater in males than in females (Fig. 4a, b). CIR mRNA expression was significantly higher in both females and males in May and June and was 1.75-2.02 times higher in males than in females $(p<0.05$; Fig. 4a, b). MIP and IGFBP_ALS mRNA expression levels were negligible in females except in September, whereas those of males were significantly higher in May and June, the maturation season ( $p$ $<0.05$; Fig. 4a, b). MIP, IGFBP_ALS, and CIR mRNA expression were relatively constant throughout the collection period (Fig. 4b) but decreased in spawning season and then increased slowly after August in both females and males (Fig. 4a, b).

$\mathrm{Vg}$ and receptor Gyc76C expression levels were examined based on their identification among male and female gonad proteins. Expression levels were high in May and then decreased until August, as observed in IGF system component expression (Fig. 5a, b). Vg showed high
mRNA expression in September; however, the difference between this and other months was not significant $(p>$ 0.05; Fig. 5a).

\section{Discussion}

It is necessary that salinity, food resources, and water flow for oyster growth (Williamson et al. 2015). The growth difference depends on the oyster farm regions affected by environmental factors such as water temperature, salinity, dissolved oxygen, nutrients, water flow and so on (Min et al. 2004). In the present study, the growth difference was not found between females and males within the same farm. In addition, it was showed positive relationship among STW/TW, $\mathrm{SH} / \mathrm{SL}$, and SW/SL.

The IGF system plays numerous roles in oyster growth and development; its components have been detected as $150-\mathrm{kDa}$ ternary complexes comprising one molecule each of IGF, IGFBP-3/IGFBP-5, and an $85 \mathrm{kDa}$ acid labile subunit (ALS) in circulation (Baxter 1994; Brogiolo et al. 2001). ALS is a glycosylated protein that binds to IGFBP-3:IGF and IGFBP-5:IGF binary complexes but does not bind to IGFBP except in complex with IGF (Brogiolo et al. 2001). The main function of ALS is to increase the half-life of IGFs in circulation (Forbes et al. 2012). The IGF insulin receptor (IGF-1R) and insulin receptor-related receptor (IRR) form subclass II of the receptor tyrosine kinase superfamily, sharing covalently 


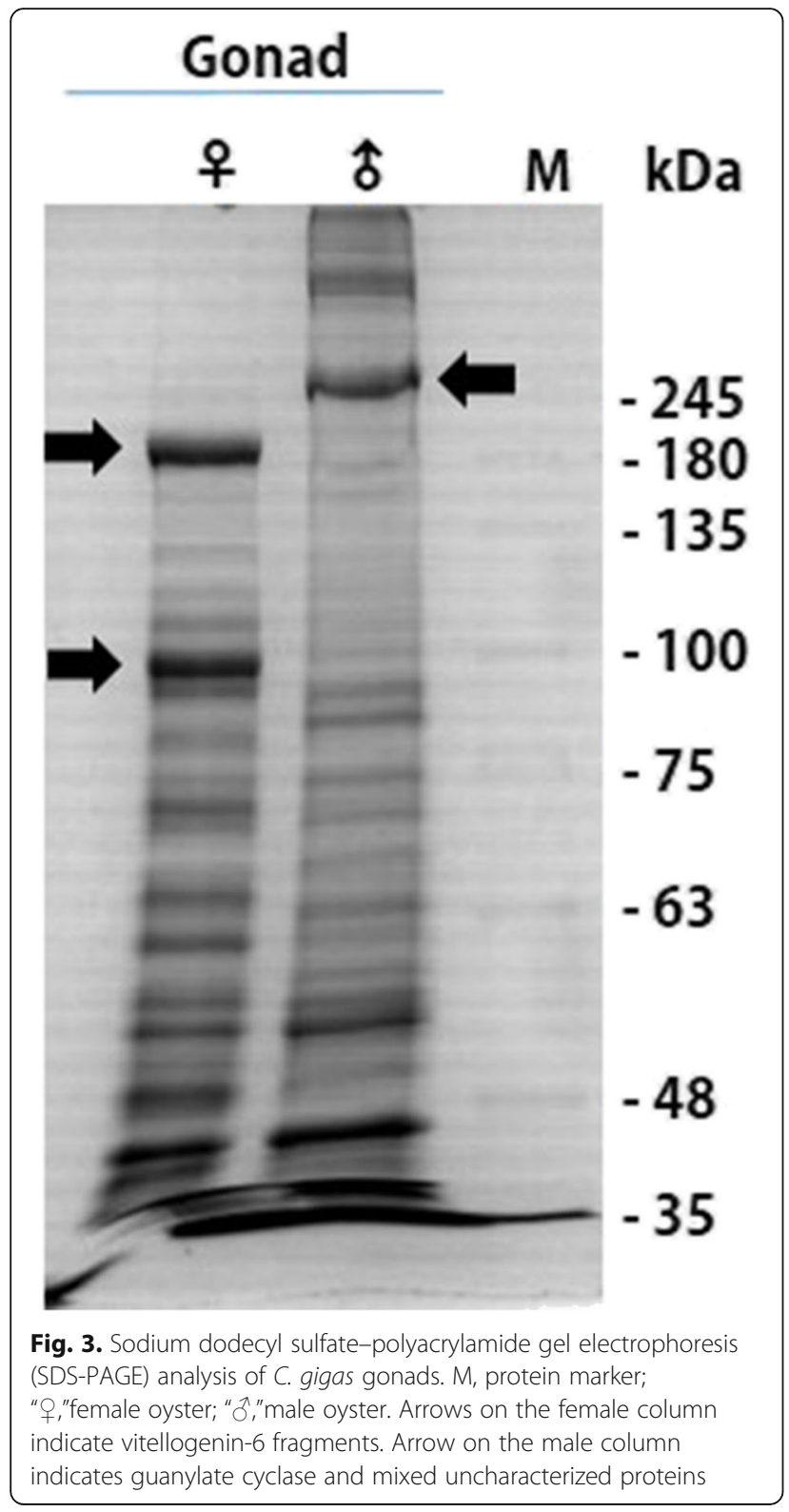

linked homodimers and several structural domains (Rentería et al. 2008). Invertebrates have only a single IRR, which regulates growth and metabolism (Leevers 2001); there is no clear evidence of the existence of traditional IGFs, IGF receptors, or IGFBP1-6 in invertebrates (Huang et al. 2015). However, several insulin-related peptides (IRPs) have been identified based on biochemical purification or cDNA identification (Cherf-Feildel et al. 2019). Various biological functions and members of the insulin family observed in vertebrates are generally conserved in invertebrates. This functional conservation has been clearly demonstrated in Drosophila melanogaster and Caenorhabditis elegans (Cherf-Feildel et al. 2019). IRPs play key roles in controlling growth, development, energy storage, stress resistance, response to diet restriction, lifespan, and fecundity in these species. Some research has also been conducted on the involvement of IRPs (molluscan IRP, MIPs) in controlling growth, reproduction, and nutritional status in $C$. gigas (Gricourt et al. 2003; Jouaux et al. 2012).

In the present study, expression levels of IGF-related genes (MIP, CIR, and IGFBP-ALS) and sex-specific genes (Vg and Gyc76C) were significantly higher in May, when oysters have matured and are about to undergo spawning. The observed changes in gene expression levels may therefore be used as indicators of annual growth, maturity, and spawning period in cultured C. gigas. The application of IGF system (MIP, IGFBP-ALS, and CIR) expression as a growth indicator is an attractive alternative to physiological methods, which are prone to processing errors (Tran et al. 2007).

IGF system component mRNA expression is associated with changes in $\mathrm{Vg}$ and Gyc76C expression. $\mathrm{Vg}$ is a major precursor of vitellins, which are egg yolk proteins that provide energy reserves for embryonic development in oviparous organisms (Matozzo et al. 2008). To date, six Vg genes (1 to 6) have been identified in the nematode Caenorhabditis elegans (Boag et al. 2001), and a female-specific Vg-6 has been identified in Haemonchus contortus (Hartman et al. 2001), Trichostrongylus vitrines (Nisbet and Gasser 2004), and Toxocara canis (Zhu et al. 2017). These $\mathrm{Vg}$ genes play roles in reproduction and may be involved in adult biological processes (Zhu et al. 2017). In the present study, we identified Vg-6 C-term and $\mathrm{N}$-term fragments in female gonads. Vg mRNA expression was highest during the maturation stage and decreased thereafter. Our results are consistent with those reported for the scallop Chlamys farreri (Qin et al. 2012) and the Fujian oyster Crassostrea angulata ( $\mathrm{Ni}$ et al. 2014). Ni et al. (2014) described the stages of oyster ovarian development in detail as follows: (1) maturation stage, when ovaries accumulate nutrients for oogenesis, and mRNA is abundant due to active $\mathrm{Vg}$ gene expression to promote $\mathrm{Vg}$ protein synthesis, yolk intake, and nutrient accumulation in oocytes; (2) ripeness stage, when oocytes grow and accumulate yolk, decreasing the demand for yolk protein and Vg gene expression; and (3) partially spent stage, when ovaries stop developing and before new oogonium inception so that $\mathrm{Vg}$ expression levels are very low (Boutet et al. 2008; Zheng et al. 2012). Davis et al. (2008) reported that endogenous in females and exogenous $\mathrm{Vg}$ in $17 \beta$-estradiol $\left(\mathrm{E}_{2}\right)$-treated males downregulate GH/IGF-1 axis support of vitellogenesis in the liver. $E_{2}$ induces the shift of energy away from somatic growth by suppressing the haptic GH/IGF axis and toward vitellogenesis by estrogen receptor $\alpha$ mediated upregulation of multiple $\mathrm{Vg}$ genes, which is 

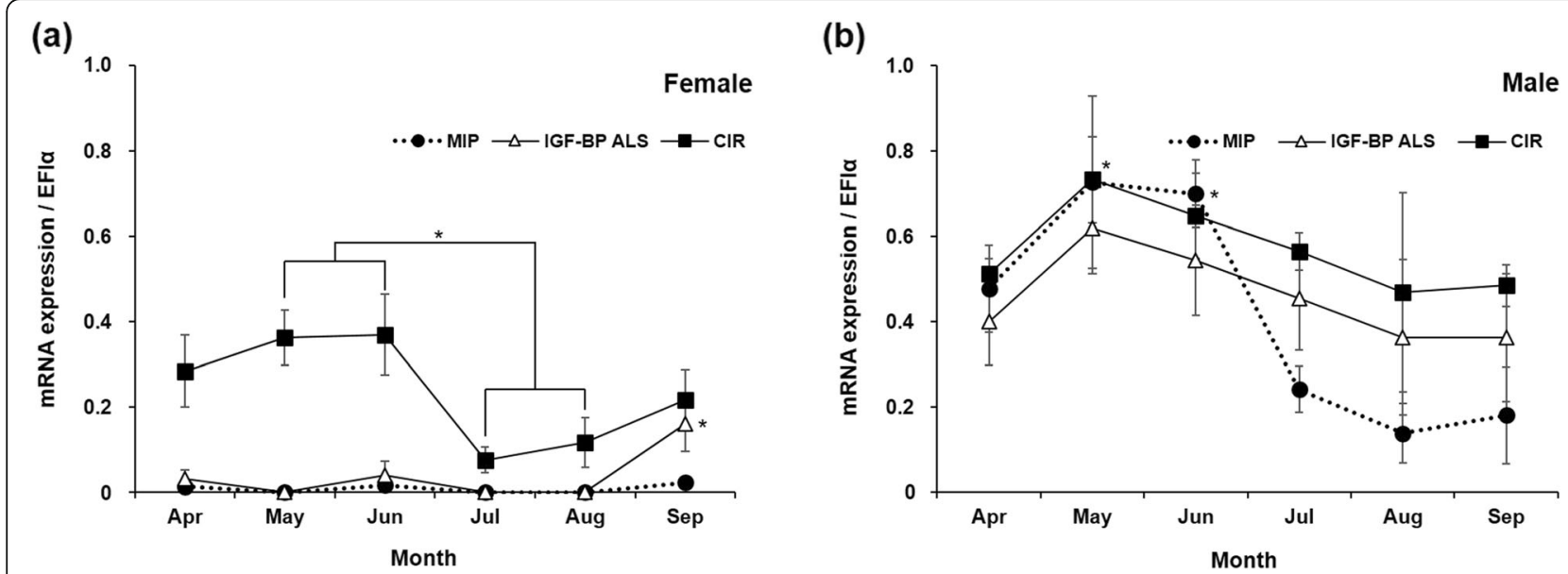

Fig. 4 Molluscan insulin-related peptide (MIP), insulin-like growth factor binding protein complex acid labile subunit (IGFBP-ALS), and C. gigas insulin receptor-related receptor (CIR) mRNA expression in C. gigas a females and $\mathbf{b}$ males

a potential endocrine mechanism contributing to sexual dimorphism (Davis et al. 2008).

Guanylate cyclase (Gyc) is a family of soluble receptor-type enzymes that catalyze the conversion of GTP to cGMP in both vertebrates and invertebrates (Patel et al. 2012). The expression of Gyc mRNA is involved in oogenesis, egg chamber development (Gigliotti et al. 1993; Ayoob et al. 2004), retinal development (Patel et al. 2012), wing development (Schleede and Blair 2015), and lumen formation (Myat and Patel 2016) in Drosophyla and in embryonic and adult retinal development in Oryzias latipes (Harumi et al. 2003). In the present study, Gyc76C mRNA expression was high in males during the maturation season, and its trends were similar to those of the IGF system. Therefore, we cautiously suggest that Gyc76C plays a sex-specific role in male oysters. IGF-1 inhibits adenylate cyclase and stimulates Gyc activity, thereby lowering cyclic AMP concentrations and elevating cycle GMP levels in a manner similar to the action of insulin
(Hadley 1988; Deeming 1991). Further studies focusing on the association between the function of cleaved $\mathrm{Vg}$ genes and the GH/IGF axis in ovaries and on Gyc and the IGF system in each developmental stage are necessary.

\section{Conclusion}

The expression of IGF system components including MIP, IGFBP-ALS, and CIR was associated with sex and developmental stage in Pacific oyster gonads. CIR and Vg expression levels were very similar among females, whereas those of MIP, IGFBP_ALS, CIR, and Gyc7C were very similar among males. The highest expression levels occurred in May, which is the maturation season. CIR and Vg are female-specific genes in Pacific oysters, whereas MIP, IGFBP-ALS, CIR, and Gyc76C are male specific. The results of the present study suggest that IGF system components, as well as $\mathrm{Vg}$ and Gyc76C, are associated with sexual maturation in C. gigas.

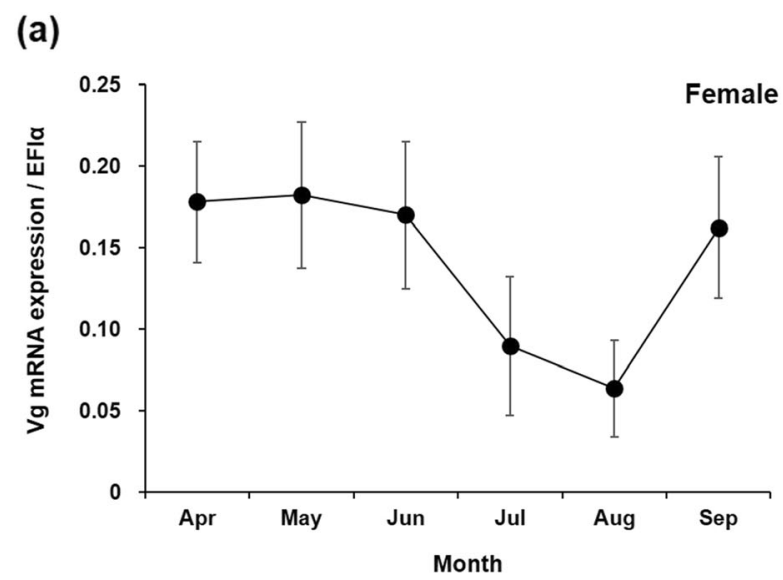

(b)

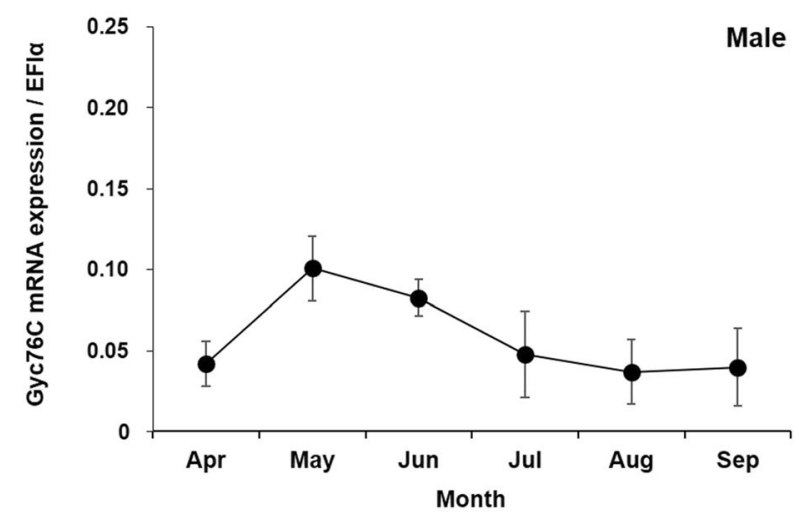

Fig. 5 Vitellogenin $(\mathrm{Vg})$ and receptor-type guanylate cyclase (Gyc76C) mRNA expression in C. gigas a females and $\mathbf{b}$ males 


\section{Acknowledgements}

Not applicable.

\section{Authors' contributions}

YHC contributed to the conceptualization, investigation, writing, supervision, project administration, and funding acquisition. JSM contributed to the investigation and data analysis. Both authors read and approved the final manuscript.

\section{Funding}

This research was supported by the Basic Science Research Program through the National Research Foundation of Korea (NRF) funded by the Ministry of Education (NRF-2016R1D1A1B03934914).

\section{Availability of data and materials}

Data sharing is not applicable to this article as no datasets were generated or analyzed during the current study.

\section{Ethics approval and consent to participate} Not applicable.

\section{Consent for publication}

Not applicable.

\section{Competing interests}

The authors declare that they have no competing interest.

Received: 6 January 2020 Accepted: 13 February 2020

Published online: 25 February 2020

\section{References}

Ayoob JC, Yu HH, Terman JR, Kolodkin AL. The Drosophila receptor quanyly cyclase Gyc76C is required for semaphoring-1a-plexin A-mediated axonal repulsion. J Neurosci. 2004:24:6639-49.

Baxter RC. Insulin-like growth factor binding proteins in the human circulation: a review. Horm Res. 1994:42:140-4.

Bayne BL. Physiological components of growth differences between individual oysters (Crassostrea gigas) and a comparison with Saccostrea commercialis. Physiol Biochem Zool. 1999;72:705-13.

Boag PR, Newton SE, Gasser RB. Molecular aspects of sexual development and reproduction in nematodes and schistosomes. Advan Parasitol. 2001; 50:153-98.

Boutet I, Moraga D, Marinovic L, Obreque J, Chavez-Crooker P. Characterization of reproduction-specific genes in a marine bivalve mollusc: influence of maturation stage and sex on mRNA expression. Gene. 2008:407:130-8.

Brogiolo W, Stocker H, Ikeya T, Rintelen F, Fernandez R, Hafen E. An evolutionarily conserved function of the Drosophila insulin receptor and insulin-like peptides in growth control. Curr Biol. 2001;11:213-21.

Canesi L, Betti M, Ciacci C, Gallo G. Insulin-like effect of zinc in Mytilus digestive gland cells: modulation of tyrosine kinase-mediated cell signaling. Gen Comp Endocrinol. 2001;122:60-6.

Canesi L, Ciacci C, Betti M, Malatesta M, Gazzanelli G, Gallo G. Growth factors stimulate the activity of key glycolytic enzymes in isolated digestive gland cells from mussels (Mytilus galloprovincialis Lam.) through tyrosine kinase mediated signal transduction. Gen Comp Endocrinol. 1999;1 16:241-8.

Canesi L, Ciacci C, Orunesu M, Gallo G. Effects of epidermal growth factor on isolated digestive gland cells from mussels (Mytilus galloprovincialis Lam.). Gen Comp Endocrinol. 1997:107:221-8.

Cherif-Feildel M, Berthelin H, Adeline B, Rivière G, Favrel P, Kellner K. Molecular evolution and functional characterization of insulin related peptides in molluscs: contributions of Crassostrea gigas genomic and transcriptomicwide screening. Gen Comp Endocrinol. 2019;271:15-29.

Choi YH, Kim EY, Nam TJ. Involvement of insulin-like growth factor in intraspecific variation in growth of Pacific oyster Crassostrea gigas during winter. Fish Sci. 2018:84:1017-24

Choi YH, Yamaguchi K, Oda T, Nam TJ. Chemical and mass spectrometry characterization of the red alga Pyropia yezoensis chemoprotective protein (PYP): protective activity of the $\mathrm{N}$-terminal fragment of PYP1 against acetaminophen-induced cell death in Chang liver cells. Int J Mol Med. 2015; 35:271-6.
Chung JS. An insulin-like growth factor found in hepatopancreas implicates carbohydrate metabolism of the blue crab Callinectes sapidus. Gen Comp Endocrinol. 2014;199:56-64.

Davis LK, Pierce AL, Hiramatsu N, Sullivan CV, Hirano T, Grau EG. Gender-specific expression of multiple estrogen receptors, growth hormone receptors, insulin-like growth factors and vitellogenins, and effects of 17b-estradiol in the male tilapia (Oreochromis mossambicus). Gen Comp Endocrinol. 2008;156: $544-51$.

Deeming DC. Egg incubation: its effects on embryonic development in birds and reptiles. UK: Cambridge University Press; 1991. p. 448.

Duan C. The insulin-like growth factor system and its biological actions in fish. Am Zool. 1997;37:491-503.

Feng L, Li X, Yu Q, Ning X, Dou J, Zou J, Zhang L, Wang S, Hu X, Bao Z. A scallop IGF binding protein gene: molecular characterization and association of variants with growth traits. PLoS One. 2014;9:e89039.

Food and Agriculture Organization. http://www.fao.org (2020). Accessed 29 January 2020.

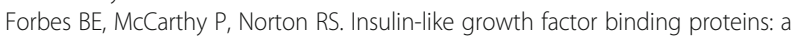
structural perspective. Front Endocrinol. 2012:3:1-13.

Geraerts WP. Control of growth by the neurosecretory hormone of the light green cells in the freshwater snail Lymnaea stagnalis. Gen Comp Endocrinol. 1976;29:61-71.

Geraerts WP. Neurohormonal control of growth and carbohydrate metabolism by the light green cells in Lymnaea stagnalis. Gen Comp Endocrinol. 1992;86: 433-44.

Geraerts WP, Smit AB, Li KW, Hordijk PL. The light green cells of Lymnaea: a neuroendocrine model system for stimulus-induced expression of multiple peptide genes in a single cell type. Experientia. 1992;48:464-73.

Gigliotti S, Cavaliere V, Manzi A, Tino A, Graziani F, Malva C. A membrane guanylate cyclase Drosophila homolog gene exhibits maternal and zygotic expression. Dev Biol. 1993;159:450-61.

Gricourt L, Bonnec G, Boujard D, Mathieu M, Kellner K. Insulin-like system and growth regulation in the Pacific oyster Crassostrea gigas: hrlGF-1 effect on protein synthesis of mantle edge cells and expression of an homologous insulin receptor-related receptor. Gen Comp Endocrinol. 2003;134:44-56.

Grönke S, Clarke DF, Broughton S, Andrews TD, Partridge L. Molecular evolution and functional characterization of Drosophila insulin-like peptides. PLOS Genet. 2010;6:e1000857.

Hadley ME. Endocrinology: 2nd ed. Prentice-Hall, Englewood Cliffs, NJ, 1988. 550 pp. In General and Comparative Endocrinology 1988;72:329-329.

Hartman D, Donald DR, Nikolaou S, Savin KW, Hasse D, J.A Presidente P, Newton SE. Analysis of developmentally regulated genes of the parasite Haemonchus contortus. Int J Parasitol. 2001;31:1236-45.

Harumi T, Watanabe T, Yamamoto T, Tanabe Y, Suzuki N. Expression of membrane-bound and soluble guanylyl cyclase mRNAs in embryonic and adult retina of the medaka fish Oryzias latipes. Zool Sci. 2003;20:133-40.

Huang $\mathrm{X}$, Ye H, Feng B, Huang H. Insights into insulin-like peptide system in invertebrates from studies on IGF binding domain-containing proteins in the female mud crab, Scylla paramamosain. Mol Cell Endocrinol. 2015;416:36-45.

Jouaux A, Franco A, Heude-Berthelin C, Sourdaine P, Blin JL, Mathieu M, Kellner K. Identification of Ras, Pten and p7056K homologs in the Pacific oyster Crassostrea gigas and diet control of insulin pathway. Gen Comp Endocrinol. 2012;176:28-38.

Krieger MJB, Jahan N, Riehle MA, Cao C, Brown MR. Molecular characterization of insulin-like peptide genes and their expression in the African malaria mosquito, Anopheles gambiae. Insect Mol Biol. 2004;13:305-15.

Leevers SJ. Growth control: invertebrate insulin surprises. Curr Biol. 2001;11:R209-12.

Macdonald BA, Thompson RJ. Intraspecific variation in growth and reproduction in latitudinally differentiated populations of the giant scallop Placopecten magellanicus (Gmelin). Biol Bull. 1988;175:361-71.

Marquez AG, Pietri JE, Smithers HM, Nuss A, Antonova Y, Drexler AL, Riehle MA Brown MR, Luckhart S. Insulin-like peptides in the mosquito Anopheles stephensi: identification and expression in response to diet and infection with Plasmodium falciparum. Gen Comp Endocrinol. 2011;173:303-12.

Matozzo V, Gagné F, Marin MG, Ricciardi F, Christian BC. Vitellogenin as a biomarker of exposure to estrogenic compounds in aquatic invertebrates: a review. Environ Int. 2008;34:531-45.

Min KS, Kim BS, Kim TI, Hur YB, Chung EY. Reproductive cycle and induced sexual maturation of the Pacific oyster. Crassostrea gigas. 2004;20:75-84.

Ministry of Oceans and Fisheries. http://www.mof.go.kr (2020). Accessed 29 January 2020. 
Myat MM, Patel U. Receptor-type guanylyl cyclase at 76C (Gyc76C) regulates De Novo lumen formation during Drosophila tracheal development. PLoS ONE. 2016;11:e0161865

Nagasawa H, Kataoka H, Isogai A, Tamura S, Suzuki A, Mizoguchi A, Fujiwara Y, Suzuki A, Takahashi SY, Ishizaki H. Amino acid sequence of a prothoracicotropic hormone of the silkworm Bombyx mori. PNAS USA. 1986; 83:5840-3.

Nässel DR, Liu Y, Luo J. Insulin/IGF signaling and its regulation in Drosophila. Gen Comp Endocrinol. 2015;221:255-66.

$\mathrm{Ni}$ J, Zeng Z, Kong D, Hou L, Huang H, Ke C. Vitellogenin of Fujian oyster, Crassostrea angulata: synthesized in the ovary and controlled by estradiol17ß. Gen Comp Endocrinol. 2014;202:35-43.

Nisbet AJ, Gasser RB. Profiling of gender-specific gene expression for Trichostrongylus vitrinus (Nematoda: Strongylida) by microarray analysis of expressed sequence tag libraries constructed by suppressive-subtractive hybridisation. Int J Parasitol. 2004;34:633-43.

Patel U, Davies SA, Myat MM. Receptor-type guanylyl cyclase Gyc76C is required for development of the Drosophila embryonic somatic muscle. Biol Open. 2012;1:507-15.

Qin Z, Li Y, Sun D, Shao M, Zhang Z. Cloning and expression analysis of the vitellogenin gene in the scallop Chlamys farreri and the effects of estradiol17b on its synthesis. Inverte Biol. 2012;131:312-21.

Rentería ME, Gandhi NS, Vinuesa P, Helmerhorst E, Mancera RL. A comparative structural bioinformatics analysis of the insulin receptor family ectodomain based on phylogenetic information. 2008;3:e3667.

Roovers E, Vincent ME, van Kesteren E, Geraerts WP, Planta RJ, Vreugdenhil E, van Heerikhuizen $\mathrm{H}$. Characterization of a putative molluscan insulin-related peptide receptor. Gene. 1995;11:81-8.

Schleede J, Blair SS. The Gyc76C receptor guanylyl cyclase and the foraging cGMP-dependent kinase regulate extracellular matrix organization and BMP signaling in the developing wing of Drosophila melanogaster. PLOS Gene. 2015;11:e1005576.

Tran TQ, Boring RL, Dudenhoeffer DD, Hallbert BP, Keller MD, Anderson TM. Advantages and disadvantages of physiological assessment for next generation control room design. Hfpp HPRCT 13th Annual Meeting 2007; IEEE 8th.

Ventura T, Rosen O, Sagi O. From the discovery of the crustacean androgenic gland to the insulin-like hormone in six decades. Gen Comp Endocrinol. 2011:173:381-8.

Williamson TR, Tilley DR, Campbell E. Emergy analysis to evaluate the sustainability of two oyster aquaculture systems in the Chesapeake Bay. Ecol Eng. 2015;85:103-20.

Wu A, Brown MR. Signaling and function of insulin-like peptides in insects. Annual Review Entomol. 2006;51:1-24.

Zheng H, Zhang Q, Liu H, Liu W, Sun Z, Li S, Zhang T. Cloning and expression of vitellogenin $(\mathrm{Vg})$ gene and its correlations with total carenoids content and total antioxidant capacity in noble scallop Chlamys nobilis (Bivalve: Pectinidae). Aquaculture. 2012;366-367:46-53.

Zhu HH, Ma GX, Luo YF, Luo YL, Yin SS, Xiong Y, Zhou RQ. Tissue distribution and functional analysis of vitellogenin-6 of Toxocara canis. Exp Parasitol. 2017;177:22-7.

\section{Publisher's Note}

Springer Nature remains neutral with regard to jurisdictional claims in published maps and institutional affiliations.

Ready to submit your research? Choose BMC and benefit from:

- fast, convenient online submission

- thorough peer review by experienced researchers in your field

- rapid publication on acceptance

- support for research data, including large and complex data types

- gold Open Access which fosters wider collaboration and increased citations

- maximum visibility for your research: over $100 \mathrm{M}$ website views per year

At $\mathrm{BMC}$, research is always in progress.

Learn more biomedcentral.com/submissions 